\title{
The influence of naphthalene acetic acid (NAA) on tipburn of internal leaves of lettuce (Lactuca sativa $\mathrm{L}_{\text {.) }}$
}

\author{
JOANNA OSTRZYCKA, JAN BORKOWSKI and LESZEK S. JANKIEWICZ
}

\author{
Research Institute of Vegetable Crops, ul. Konstytucji 3 Maja 1/3, \\ 96-100 Skierniewice, Poland
}

(Received: December 31, 1986)

\begin{abstract}
NAA potassium salt (preparation Pomonit) applied at a concentration of $25 \mathrm{mg} \cdot \mathrm{dm}^{-3}$ markedly inhibited tipburn of internal leaves in lettuce plants grown in a greenhouse. Reduction of tipburn symptoms ranged from 9.6 to $96.9 \%$ depending on the cultivar. In the internal leaves, on which the disorder usually appears, the calcium level was generally lower and the level of phenolic substances higher. Treating the plants with a potassium salt of NAA, 2-3 weeks before harvest usually caused a rise of the $\mathrm{Ca}^{++}$level and a decrease in the level of phenolic substances in the internal leaves. The NAA potassium salt was rapidly degraded in the plant and after only 24 hours was almost undetectable by a method sensitive to $0.3 \mu \mathrm{g} \mathrm{NAA} \cdot \mathrm{g}^{-1}$ fresh matter, therefore it is probable that NAA treatment may be permitted in practice.
\end{abstract}

Lettuce plants cultivated in a greenhouse are frequently affected by tipburn of internal leaves. The sympotm of this disease is necrosis of internal leaves starting with their margins (Thibodeau and Minotti, 1969; Collier and Huntington, 1983; Yanagi and Bullock, 1983; Borkowski and Bereśniewicz 1985).

Low calcium content in leaves, and all factors which stimulate the growth, for instance, high temperature, high light intensity, the increased concentration of $\mathrm{CO}_{2}$, etc. foster the occurrence of the disorder (Collie r and Tibbits, 1982). For instance, tipburn symptoms appear some days after elevating the temperature in a greenhouse to $30^{\circ} \mathrm{C}$ (Misaghi and Grogan, 1978a,b).

According to Collier (1976) the necrosis of internal lettuce leaves may result from the increased level of chlorogenic acid which inhibits IAA oxidase, this, in consequence, leads to an augmented auxin level in a plant and growth stimulation, favouring that way the appearance of latex tipburn. Nevertheless Borkowski (1981) and Borkowski et al. (1984) have found that spraying the lettuce plants with a synthetic auxin (NAA) drastically inhibits the appearance of the disorder. 
The present paper reports further investigations on the inhibitory action of NAA in tipburn using several lettuce cultivars of different susceptibility to the disorder. Trials were also undertaken to check if there is any correlation between sensitivity to tipburn and the content of calcium and phenolic compounds in the plants. Since NAA treatment is easy to apply in practice, the residues of this compound were also studied in lettuce leaves in order to facilitate the registration of NAA application for lettuce.

\section{MATERIAL AND METHODS}

THE METHODS OF AGROTECHNICAL INVESTIGATION

The experiment was set up in 1983 in a greenhouse of the Greenhouse Experimental Station in Skierniewice. Five lettuce cultivars (Lactuca sativa L.) differing in their susceptibility to the disorder were used (see Table 1).

\section{Table 1}

The influence of NAA (as potassium salt) $25 \mathrm{mg} \cdot \mathrm{dm}^{-3}$ on the occurrence of latex tipburn in different lettuce cultivars

\begin{tabular}{llcc}
\hline Cultivar & Treatment & $\begin{array}{c}\text { Degree of } \\
\text { disorder }\end{array}$ & $\begin{array}{c}\text { Tipburn } \\
\text { reduction } \\
\text { after NAA } \\
\text { treatment \% }\end{array}$ \\
\hline Kwiek & control & 0.99 & \\
& NAA & 0.77 & 22.2 \\
\hline Ilanka & control & 0.81 & \\
& NAA & $0.03^{*}$ & 96.3 \\
\hline Deci Minor & control & 0.52 & \\
& NAA & 0.47 & 9.6 \\
\hline Marcia & control & 0.33 \\
\hline Orba & NAA & $0.01 *$ & 96.9 \\
\hline & control & NAA & 0.30 \\
* In each pair of values marked with * the difference is significant at $P=0.01$, using $\chi^{2}$ \\
* Tipburn degree in a $0-4$ scale.
\end{tabular}

The plants were grown on tables with a peat substrate containing the following minerals (in $\mathrm{mg} \cdot \mathrm{dm}^{-3}$ ): $\mathrm{N}-370, \mathrm{P}-420, \mathrm{~K}-920, \mathrm{Mg}-264, \mathrm{Ca}-$ 2180. Additionally, potassium sulphate was added at $530 \mathrm{mg} \cdot \mathrm{dm}^{-3}$ during growth. The number of plants in one plot was 45 . There were 4 blocks (repetitions). 
The plants were sprayed with Pomonit (a Polish preparation containing NAA potassium salt) about 2-3 weeks before harvest, applying $10 \mathrm{~cm}^{3}$ solution per plant (at a concentration of $25 \mathrm{mg} \cdot \mathrm{dm}^{-3}$ NAA). The observation of latex tipburn occurrence was done on 3 successive dates using the van Andel scale (1966). According to it completly healthy plants received 0 points and plants heavily affected by the disorder -4 points. Plants with inner leaves necrotic or $90 \%$ rotten were classified as heavily affected. In addition to plants evaluated for tipburn some were preserved for chemical analysis (see further text).

\section{THE METHODS OF CHEMICAL ANALYSIS}

The lettuce plants for analysis were taken during harvest. The sample was composed of 6 plants taken randomly (one or two from one plot). In the case of determination of $\mathrm{Ca}$ and phenolic substances, the heads were divided into halves and then the external and internal leaves were separated to be analysed apart. The heads were divided into parts because we anticipated that the internal leaves, which usually are affected by the disease, would show the biochemical changes connected with the disease more distinctly. Sometimes, however, whole heads were analysed (for instance of cv. Orba).

The tests for NAA residues 10 days after treatment were done on the whole heads of all investigated cultivars. The dynamics of NAA disappearance was investigated on cv. Kwiek and As-44, analysing the lettuce 2, 5, 7,9 and 12 days or 3, 6 and 9 days, respectively, after Pomonit treatment (R a ndall, 1970).

\section{Determination of the content of phenolic substances}

The lettuce leaves or plants were crushed well and dried for 10 minutes at $105^{\circ} \mathrm{C}$ and subsequently for about $18 \mathrm{~h}$ at $60^{\circ} \mathrm{C}$. Phenolic substances were determined by taking $250 \mathrm{mg}$ of the ground plant matter and extracting it with $50 \mathrm{~cm}^{3} 96 \%$ methanol for $30 \mathrm{~min}$. The extract was diluted with water to a volume of $100 \mathrm{~cm}^{3}$ then filtered. The filtrate was used for determination of the content of phenolic substances by the method of Swain and Hills (1959) using the Folin reagent. The extinction of the solution was measured after 1 hour at $x=725 \mathrm{~nm}$ against a blank containing the reagents only. A standard curve was made with chlorogenic acid at a concentration range of $0.01-0.05 \mathrm{mg}$.

\section{Determination of calcium content}

A $0.5 \mathrm{~g}$ sample of dry material was wetted with $1 \mathrm{~cm}^{3}$ of a $5 \%$ solution of sulphuric acid in ethyl alcohol. The material was digested at $400-500^{\circ} \mathrm{C}$ for $2 \mathrm{~h}$ (the Johanson-Ulrich method, see Now osielsk $\mathrm{i}, 1968$ ). The ashes were dissolved in $50 \mathrm{~cm}^{3}$ of water with $0.7 \mathrm{~cm}^{3}$ hydrochloric acid added. Calcium was then assayed in a Zeiss flame photometer. 


\section{Determination of the NAA residues}

A method similar to that of R andall (1970) was used. $100 \mathrm{~g}$ fresh weight sample of well crushed lettuce was taken and homogenized in $10 \mathrm{~cm}^{3}$ $1 \mathrm{~N} \mathrm{H}_{2} \mathrm{SO}_{4}+400 \mathrm{~cm}^{3}$ chloroform for $3 \mathrm{~min}$. The homogenate separated into two layers and only $200 \mathrm{~cm}^{3}$ of the lower chloroform layer were taken for further analysis. After solvent evaporation, the residue was dissolved in $2 \times 5$ $\mathrm{cm}^{3}$ chloroform and purified further on a chromatographic column $2 \mathrm{~cm}$ in diameter filled with Florisil (Funk) to $8 \mathrm{~cm}$. The column was washed in the following sequence: $100 \mathrm{~cm}^{3}$ acetonitrile, $100 \mathrm{~cm}^{3}$ etyl ether, $100 \mathrm{~cm}^{3} 1 \%$ acetic acid in chloroform. The first 2 eluates were rejected, the last, containing NAA, was transfered to a separatory funnel, $50 \mathrm{~cm}^{3}$ of $1 \mathrm{~N} \mathrm{H}_{2} \mathrm{SO}_{4}$ were added and vigorously shaken. The chloroform layer was extracted successively with 50 $\mathrm{cm}^{3}$ water and $50 \mathrm{~cm}^{3}$ of $0.5 \mathrm{M} \mathrm{Na}_{2} \mathrm{HPO}_{4}$. The NAA residues were determined spectrophotometrically in an $\mathrm{Na}_{2} \mathrm{HPO}_{4}$ solution. The standard curve was made by adding $0.05,0.1,0.25$ and $0.5 \mathrm{mg} \mathrm{NAA} / 50 \mathrm{~cm}^{3} 0.5 \mathrm{M} \mathrm{Na}_{2} \mathrm{HPO}_{4}$ to the blank samples. Spectrophotometric measurements were also done with control samples in order to eliminate the so called apparent NAA, which could come from impurities.

\section{RESULTS}

The plants of 5 lettuce cultivars were grown in the period from January to March. They were moderately affected with tipburn (Table 1). The cvs. Kwiek and Ilanka were most susceptible, Deci Minor was moderately susceptible and Orba and Marcia were the least susceptible (Table 1).

Treating the plants with NAA at a concentration of $25 \mathrm{mg} \cdot \mathrm{dm}^{-3} 2$ weeks before harvest markedly lowered the degree of tipburn prevalence, however, NAA differently affected the individual cultivars (Table 1). NAA decreased the occurrence of tipburn by $96 \%$ in cv. Ilanka, by $97 \%$ in cv. Marcia, while in the cvs. Kwiek, Deci Minor and Orba the effect of NAA was insignificant.

The $\mathrm{Ca}$ content in each of the investigated cultivars was 2-3 times lower in the inner leaves, i.e. in those which usually show the symptoms of tipburn, than in the outer ones. The differences in the susceptibility of the cultivars to latex tipburn were not correlated with the absolute calcium content in the inner leaves or with the difference in the calcium content between the outer and inner leaves (Tables 1 and 2).

The inner leaves usually exhibited a higher content of phenolic substances and this difference was larger in the susceptible cultivars. Treatment with NAA always lowered the content of phenolic substances in the inner leaves or in the whole heads of cv. Orba whereas this was observed only sometimes in the outer leaves (cvs. Ilanka and Marcia) (Table 3). 
Table 2

Calcium content in the leaves of lettuce cultivars treated with NAA at $25 \mathrm{mg} \cdot \mathrm{dm}^{-3}$ (as potassium salt)

\begin{tabular}{|c|c|c|c|c|}
\hline \multirow{3}{*}{ Cultivar } & \multirow{3}{*}{ Treatment } & \multicolumn{3}{|c|}{$\begin{array}{l}\text { Content of calcium } \\
\mathrm{mg} \cdot \mathrm{g}^{-1} \text { dry matter }\end{array}$} \\
\hline & & \multicolumn{2}{|c|}{ leaves } & \multirow{2}{*}{$\begin{array}{l}\text { whole } \\
\text { head }\end{array}$} \\
\hline & & inner & outer & \\
\hline \multirow[t]{2}{*}{ Kwiek } & control & $536.0 \mathrm{a}$ & $1669.0 \mathrm{a}$ & - \\
\hline & NAA & $525.0 \mathrm{a}$ & $1808.0 \mathrm{~b}$ & - \\
\hline \multirow[t]{2}{*}{ Ilanka } & control & $676.2 \mathrm{a}$ & $1553.6 \mathrm{a}$ & 1114.4 \\
\hline & NAA & $772.8 \mathrm{~b}$ & $1561.7 \mathrm{a}$ & - \\
\hline \multirow[t]{2}{*}{ Deci Minor } & control & $595.7 \mathrm{~b}$ & $1424.8 \mathrm{a}$ & $1014.0 \mathrm{a}$ \\
\hline & NAA & 523.2 a & $1512.0 \mathrm{~b}$ & $1188.0 \mathrm{~b}$ \\
\hline \multirow[t]{2}{*}{ Marcia } & control & $625.0 \mathrm{a}$ & $1669.0 \mathrm{a}$ & - \\
\hline & NAA & $787.0 \mathrm{~b}$ & $1808.0 \mathrm{~b}$ & - \\
\hline \multirow[t]{2}{*}{ Orba } & control & - & - & $1070.6 \mathrm{a}$ \\
\hline & NAA & - & - & $1263.8 \mathrm{~b}$ \\
\hline
\end{tabular}

In each pair, the values marked with different letters differ at $P=0.05$ using $t$ Student's test for significance.

Table 3

Content of phenolic compounds in leaves of lettuce cultivars treated or not treated with NAA (as potassium salt) at $25 \mathrm{mg} \cdot \mathrm{dm}^{-3}$

\begin{tabular}{llrrr}
\hline & & \multicolumn{2}{c}{$\begin{array}{c}\text { Content of phenolic compounds } \\
\mathrm{mg} \cdot \mathrm{g}^{-1} \text { dry matter }\end{array}$} \\
\cline { 3 - 5 } Cultivar & Treatment & \multicolumn{3}{c}{$\begin{array}{c}\text { whole } \\
\text { head }\end{array}$} \\
\cline { 3 - 5 } & & leaves & - \\
\cline { 3 - 5 } Kwiek & control & $21.8 \mathrm{~b}$ & $3.5 \mathrm{a}$ & - \\
& NAA & $14.4 \mathrm{a}$ & $3.3 \mathrm{a}$ & - \\
& control & $14.1 \mathrm{~b}$ & $10.2 \mathrm{~b}$ & - \\
\hline Ilanka & NAA & $10.7 \mathrm{a}$ & $8.1 \mathrm{a}$ & - \\
& control & $12.0 \mathrm{~b}$ & $6.0 \mathrm{a}$ & - \\
\hline Deci Minor & NAA & $8.9 \mathrm{a}$ & $6.7 \mathrm{a}$ & - \\
\hline Marcia & control & $12.0 \mathrm{~b}$ & $6.2 \mathrm{~b}$ & - \\
& NAA & $5.7 \mathrm{a}$ & $4.9 \mathrm{a}$ & - \\
\hline Orba & control & - & - & $6.6 \mathrm{~b}$ \\
& NAA & - & - & $5.6 \mathrm{a}$ \\
\hline
\end{tabular}

In each pair, the values marked with different letters differ at $P=0.05$ using $t$ Student's test for significance. 
The residues in all of the tested cultivars were already at, or below the 1988; Borkowski et al., 1984) showed that NAA may drastically lower application of the growth regulator.

\section{DISCUSSION}

The results presented in this paper and in earlier ones (Borkowski, 1981, 1988; Borkowski et al., 1984) showed that NAA may drastically lower the incidence of tipburn in several greenhouse lettuce cultivars. We have not encountered any mention of such an effect in literature. Collier (1976) claims that high levels of endogenous auxin (IAA) may stimulate lettuce growth and increase in this manner the occurrence of tipburn. Since Grochowska and Karaszewska (1974) have shown that, at least in the apple tree, NAA may lower the level of endogenous auxins the following mechanism might be suggested: NAA $\rightarrow$ lowering of endogenous auxins level $\rightarrow$ growth inhibition $\rightarrow$ reduction of latex tipburn occurrence.

In our opinion this mechanism is not very probable since NAA in concentrations up to $50 \mathrm{mg} \cdot \mathrm{dm}^{-3}$ does not inhibit lettuce growth even if two consecutive applications were done (Borkowski, 1981, 1988).

Several authors suggest that tipburn of internal leaves is connected with calcium deficiency. For instance Thibodeau and Minotti (1969) suggest that tipburn results from inadequate supply of soluble calcium during some critical period. A sk ar and Ries (1971) conclude that the calcium content near the leaf regions affected by this disorder was lower than in the rest of the leaf. On trying to influence the calcium content in lettuce leaves, B art and Tib bits (1986) enclosed parts of the leaves in polyethylene bags. This treatment diminished transpiration and by this manner also the calcium supply to the enclosed parts of the leaf. They observed a decrease of calcium content and heavier latex tipburn symptoms in the parts of the leaves enclosed in the bags.

In our experiment NAA caused a tendency to form loose heads and delayed head formation. Therefore one may suppose that the resulting increased transpiration may lead to better $\mathrm{Ca}^{++}$supply to the inner levaes which would prevent tipburn development. Our results only partially support this hypothesis: in the majority of cases the NAA treated plants did contain more calcium than controls in whole heads or in the inner or outer leaves only. However, the differences were small and sometimes even the reverse relation occurred.

The other conception concerning the cause of latex tipburn implies a higher content of organic acids under conditions favuoring tipburn. For instance at a higher temperature, respiration is markedly increased and the content of such Krebs Cycle acids as citric, isocitric, succinic etc. increase. These acids may chelate $\mathrm{Ca}^{++}$ions. Especially chelates of citric acid with $\mathrm{Ca}^{++}$are formed easily and may make calcium less available. Misaghi and Grogan (1978b) were able to induce latex tipburn symptoms in several lettuce cultivars which 
normally are little susceptible to this disorder by treating them with citric acid.

On the other hand, Collier (1976) has found that lettuce cultivars which were more susceptible to tipburn contained more chlorogenic acid, a polyphenol. We investigated the total content of phenols in the plants and have found in the inner leaves a similar tendency as that observed by Collier: the more susceptible the cultivar, the more phenols it contained. Moreover, we have found that the outer leaves which were less affected by tipburn contained much less phenolic substances. We also found that NAA treatment which decreased tipburn diminished the content of phenols in the inner leaves.

All these data suggest that there exists a rather good correlation between tipburn and content of phenolic substances. What the nature is of this correlation is difficult to say at present. For chlorogenic acid, Collier (1976) suggests the following role: chlorogenic acid as a polyphenol suppresses IAA oxidase, this causes an increase of the IAA level which results in growth stimulation and tipburn usually occurs in fast growing plants. As was mentioned, we do not believe that this explanation is true in our case, since the plants treated with NAA showed less tipburn and a lower level of phenolic substances but their growth was not suppressed. It seems more likely that phenolic substances, several of which have chelating properties (Oota, 1975) may act as chelating agents diminishing in effect $\mathrm{Ca}^{2+}$ availability. It remains, however, to be explained how NAA lowers the level of phenolic substances. It would also be interesting which particular phenols are mainly connected with the development of tipburn symptoms.

Besides these theoretical problems there remains the problem of practical application of NAA to diminish the tipburn symptoms. NAA is a compound of low toxicity (4th group of toxicity) and is rapidly metabolized in the tissues. On the first day after spraying with NAA its residues were at the limit of detection. Due to this, NAA treatment against latex tipburn is already permitted in Poland on a limited scale.

\section{REFERENCES}

Andel van O. M., 1966. Mode of action of threo-B-phenylserine as a chemotherapeutant of cucumber scab. Nature, 211: 326-327.

Askar S. A., Ries S. K., 1971. Lettuce tipburn as related to nutrient imbalance and nitrogen composition. J. Amer. Hort. Sci. 96 (4): 448-452.

Bart D. J., Tibbitts T. W., 1986. Effects of artificial enclosure of young lettuce leaves on tipburn incidence and leaf calcium concentration. J. Amer. Soc. Hort. Sci. 111 (3): 413-416.

Borkowski J. 1981. Wpływ kwasu $\alpha$-naftylooctowego na występowanie chorób fizjologicznych u sałaty. Ogrodnictwo, 18 (1): 14-15.

Borkowski J. 1988. Wpływ regulatorów wzrostu na zdrowotność, wzrost i wybijanie sałaty w pędy kwiatostanowe. Acta Agrobot. 41: 275-284.

Borkowski J., Bereśniewicz A. 1985. Wpływ wapnowania popiołem z węgla brunatnego na występowanie chorób fizjologicznych sałaty. Biul. Warz. Skierniewice, 28: 9-26.

Borkowski J., Ostrzycka J., Glapś T., 1984. Wpływ kwasu $\alpha$-naftylooctowego na zamieranie 
liści zwijających główkę sałaty uprawianej w szklarni oraz pozostałości NAA w liściach. Sympozjum Naukowe z okazji XX-lecia Instytutu Warzywnictwa, X-lecia Szklarniowego Z-du Doświadczalnego, Skierniewice 1984, 237-238.

Collier G. F., 1976. Physiological considerations of lettuce tipburn. National Research Station. Wellesburne Warwick. An. Rep. 27: 44.

Collier G. F., Huntington V. C., 1983. The relationship between leaf growth, calcium accumulation and distribution and tipburn development in field-grown butterhead lettuce. Scientia Hortic. 21: 123-128.

Collier G. F., Tibbitts T. W., 1982. Tipburn of lettuce. Horticultural Reviews, 2: 49-67.

Grochowska M. J., Karaszewska A., 1974. The effect of naphthaleneacetic acid sprays on the rate of decarboxylation of ${ }^{14} \mathrm{C}$-labelled indoleacetic acid in apple leaves. [In:] Biochemistry and chemistry of plant growth regulators. An international symposium Held in Cottbus, German Democratic Republic, September 24-26 1974. Schreiber K., Schütte H. R., Sembdner G. (eds.), pp. 345-352.

Misaghi I. J., Grogan R. G. 1978a. Effect of temperature on tipburn development in head lettuce. Phytopathology, 68: 1738-1743.

Mis aghi I. J., Groga n R. G. 1978b. Physiological basis for tipburn development in head lettuce. Phytopathology, 68: 1944-1953.

Nowosielski O. 1968. Metody oznaczania potrzeb nawożenia. PWR i L, Warszawa.

Oota Y. 1975. Short-day flowering of Lemna gibba G3 induced by salicylic acid. Plant Cell Physiol. 16: 1131-1135.

Randa11 R. C. 1970. Determination of NAA residues in apples and potatoes. J. AOAC 63, 1, 149. Swain T. and Hills W. E. 1959. The quantitative analysis of phenolic constituents. J. Sci. Food Agric. 10: 63-68.

Thibodeau P. O., Minotti P. L. 1969. Influence of calcium on the development of lettuce tipburn. Proc. Amer. Soc. Hort. Sci. 94: 372-373.

Yanagi A. A., Bullock R. M. 1983. Factors involved in the development of tipburn in crisphead lettuce in Hawaii. J. Amer. Soc. Hort. Sci. 108: 234-237.

\section{Wpływ kwasu $\alpha$-naftylooctowego (NAA) na zamieranie liści wewnętrznych sałaty}

\section{Streszczenie}

Pomonit (sól potasowa NAA) w stężeniu $25 \mathrm{mg} \cdot \mathrm{dm}^{-3}$ zapobiegał zaburzeniu fizjologicznego zamierania liści wewnętrznych salaty. Zmniejszenie występowania tej choroby zależało od odmiany i wynosiło od 9,6-96\%. Liście wewnętrzne sałaty, na których choroba ta głównie występuje, zawierały znacznie mniej $\mathrm{Ca}^{++}$i zwykle więcej związków fenolowych niż liście zewnętrzne. Traktowanie sałaty solą potasową NAA niekiedy zwiększało poziom $\mathrm{Ca}^{++}$i na ogól wpływało na obniżenie zawartości związków fenolowych w liściach wewnętrznych. Sól potasowa NAA ulegała w sałacie szybkiej przemianie metabolicznej, gdyż po 24 godzinach od traktowania nie stwierdzono jej w liściach przy czułości metody $0,3 \mu \mathrm{g} \mathrm{NAA} \cdot \mathrm{g}^{-1}$ świeżej masy. 